\title{
LIVING AND TEACHING DURING COVID-19: THE DAMAGES AND BENEFITS OF TELEWORK
}

\author{
Sorina loana MIȘU \\ Bucharest University of Economic Studies, Bucharest, Romania \\ sorinaioana.misu@man.ase.ro \\ Monica TRICULESCU \\ Bucharest University of Economic Studies, Bucharest, Romania \\ monica.triculescu@man.ase.ro
}

\begin{abstract}
The pandemic of COVID-19 represented a turning point for educational systems across the world, whether we speak of pre-university systems or university ones. As most of the teaching activities used to happen within offline contexts, moving almost all the processes in an online environment represented a huge challenge for everybody. Thousands of people had to adapt to telework overnight and this situation brought both opportunities as well as unpleasant changes. Hence, the present paper, through descriptive research, intends to analyze from the teachers' point of view, the damages and benefits of telework over the past year and a half. It is our intention in the present study to highlight thoroughly the features of telework in the Romanian educational system, along with an inventory of teachers' perspectives regarding this change. We assume that such a study is of great importance as the pandemic is not over yet and we envision a future in which telework will become a normal part of the teaching activities. Thereafter, learning from today's lessons will help us all build a better tomorrow for teaching the next generations.
\end{abstract}

Keywords: teaching, telework, educational system, pandemic, human resources management

DOI: https://doi.org/10.24818/beman/2021.S.I.2-10

\section{INTRODUCTION}

As the COVID-19 pandemic obliged educational systems to implement distance learning (Alquirshi, 2020; Debacq et al., 2021; Ghasem et al., 2021), most academics feel like in a roller-coaster for the past year and a half. Situations varied from new ones, unthinkable ones, challenging ones, difficult ones - teachers, students, principals, parents, they have all been part of this ride.

Starting March $11^{\text {th }} 2020$, Romanian pre-university schools, kindergartens, and partially universities stopped their face-to-face classes. This brought along a state of confusion as nobody was prepared for this scenario, hence schools were mostly left on their own. Until the end of the 2019/2020 school year, only students who were preparing for the final exams went to special classes in the last two weeks of the school year. The rest 
of them were left at home, in the online system that every school had adopted. During the school year of 2020/2021, various scenarios were put into action, leaving most of the educational stakeholders full of doubts at many times. Romanian pre-university schools started in a hybrid scenario, meaning that half of the students were at home, watching the teacher from their home devices, while the other half was attending from the classroom. Nevertheless, this scenario lasted for only one month, when officially all pre-university schools went online until the start of the second semester. On the $8^{\text {th }}$ of February 2021, students from primary classes went back to school, face to face with their teachers. They were followed by students in their final years by the end of April 2021 and by all the rest of the students in mid-May 2021. The school year of $2020 / 2021$ officially ended on the $25^{\text {th }}$ of June 2021 . Figure 1 shows a better chronology of the Romanian pre-university schools during March 2020-June 2021.

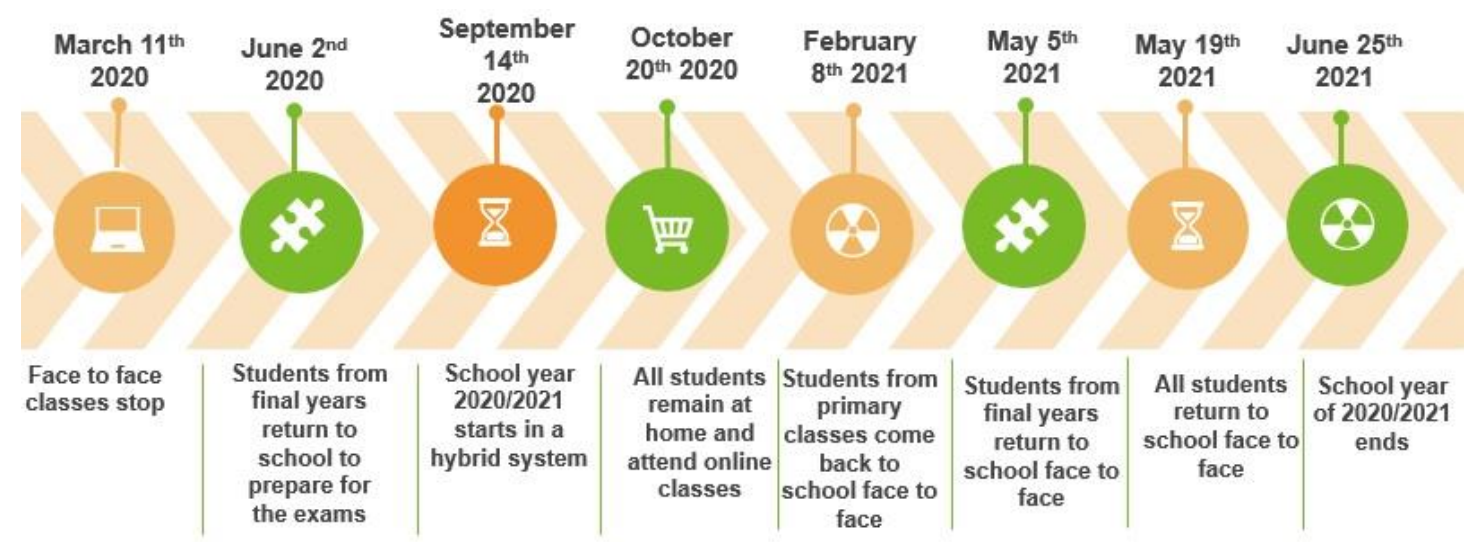

FIGURE 1. THE CHRONOLOGY OF SCENARIOS IN WHICH ROMANIAN SCHOOLS FUNCTIONED DURING MARCH 2020 - JUNE 2021

Source: Authors' contribution

As we can notice from figure 1, many changes happened during a very low amount of time, hence mechanisms of coping and adaption must have been triggered in teachers, students, and parents. For this reason, the present paper intends to explore more the teachers' perspective of this time frame in which they had to face constant changes in their work routine.

\section{LITERATURE REVIEW}

Most of the research papers available on the topic describe the challenges of distance learning (Misu, 2020; Radu, 2021). However, there is one perspective few of them bring to light. The pandemic of COVID-19 brought the opportunity for reform for the educational systems in the information age (Li et al., 2020). Schools and universities were obliged to include technological tools into their daily teaching methods and to come up with solutions to make them part of the daily activities. However, was the human resource prepared for 
this leap into the present? This is one of the main questions this paper tries to answer, based on the experience the Romanian teachers had for the past year and a half. Radu (2021) shows that up to a third of the teachers felt confused, struggled with learning fast difficult skills and some of them felt frustrated for not having procedures, universal rules to follow, or a national agreed platform.

\section{METHODOLOGY}

This part of the paper has the role to highlight the methods that have been used to fundament the conclusions we are going to present.

First of all, the main goal of this paper is to present the damages and benefits of telework while living and teaching during COVID-19 by showing the teachers' perception before and after the school year of 2020/2021.

For this descriptive research, we have used a mix of instruments, meaning, an online survey, and interviews conducted with pre-university teachers. We considered that the data we gathered will be more relevant by using both a quantitative and qualitative approach.

The online survey was conducted in September 2020, on a group of 77 pre-university teachers from Bucharest, Romania. The mean age of teachers from this survey was 38 years old. The interviews were conducted in September 2021, on a group of 15 teachers from 3 high schools in Bucharest, Romania. The mean age of the interviewed teachers was 33 years old. In both of the groups, females were predominant, in a percentage of more than $90 \%$. Table 1 shows a graphic representation of these data.

TABLE 1. DEMOGRAPHICAL DATA ABOUT THE RESPONDENTS

\begin{tabular}{|c|l|l|}
\hline & \multicolumn{1}{|c|}{ ONLINE SURVEY } & \multicolumn{1}{c|}{ INTERVIEW } \\
\hline TIME REPRESENTATION & September 2020 & September 2021 \\
\hline NUMBER OF PARTICIPANTS & 77 people & 15 people \\
\hline MEAN AGE & 38 years old & 33 years old \\
\hline GENDER REPRESENTATION & Females $-91 \%$ & Females $-97 \%$ \\
& Males $-9 \%$ & Males $-3 \%$ \\
\hline
\end{tabular}

SOURCE: AUTHORS' CONTRIBUTION

\section{RESULTS AND DISCUSSIONS}

This section of the present research paper focuses on analysing the results of the data we have gathered. We additionally focus on interpreting keeping in mind the context in which the respondents have been so that the discussion to be as valuable as it can be for the potential stakeholders. 
Mișu, S-I, Triculescu, M.

LIVING AND TEACHING DURING COVID-19: THE DAMAGES AND BENEFITS OF TELEWORK

Inventory of the damages and benefits that telework occurred to the educational process September 2020

In September 2020, after a semester of online teaching and being in front of a potential school year of more online teaching, teachers were asked to assess the positive aspects of telework in education as well as the less pleasant ones. Tables 2 and 3 show us the ranking of challenges and benefits teachers observed in telework.

TABLE 2. CHALLENGES OF TELEWORK FELT BY PRE-UNIVERSITY TEACHERS ( $\mathrm{N}=77$ )

\begin{tabular}{|c|c|}
\hline TYPE OF CHALLENGE & PERCENTAGE \\
\hline LEARNING NEW IT\&C SKILLS AND TRANSFORMING OFFLINE CLASSES INTO ONLINE CLASSES & $30 \%$ \\
\hline KEEPING THE STUDENTS' INTEREST ALIVE & $21 \%$ \\
\hline STAYING IN TOUCH WITH STUDENTS & $14 \%$ \\
\hline ADAPTING TO CHANGES & $10 \%$ \\
\hline THE FEELING OF UNCERTAINTY & $8 \%$ \\
\hline EVERYTHING & $5 \%$ \\
\hline THE EVALUATION SYSTEM & $4 \%$ \\
\hline NOTHING & $4 \%$ \\
\hline OTHER REASONS & $4 \%$ \\
\hline
\end{tabular}

SOURCE: AUTHORS' CONTRIBUTION

TABLE 3. BENEFITS OF TELEWORK OBSERVED BY PRE-UNIVERSITY TEACHERS ( $\mathrm{N}=77$ )

\begin{tabular}{|c|c|}
\hline TYPE OF BENEFIT & PERCENTAGE \\
\hline LEARNING AND DEVELOPING IT\&C SKILLS & $47 \%$ \\
\hline MORE FREE TIME FOR THE SELF, THE FAMILY, AND THE PERSONAL PROJECTS & $21 \%$ \\
\hline NONE & $21 \%$ \\
\hline MORE RESOURCES TO OFFER TO THE STUDENTS & $9 \%$ \\
\hline OTHER BENEFITS & $3 \%$ \\
\hline
\end{tabular}

SOURCE: AUTHORS' CONTRIBUTION

As we can notice from both Table 2 and Table 3, dealing with new technologies represented both the biggest challenge for pre-university teachers, as well as their greatest benefit from this change of work style. Learning how to use the teaching platforms, how to design classes taught in an online way, how to look up for materials, as well to engage with students in a virtual environment represented a huge change of paradigm for teachers. Thereafter, as figures from Table 3 show us, almost half of the questioned teachers, $47 \%$, eventually appreciated the opportunity to learn something new and to modernize their methods and 
skills. Additionally, as Radu (2021) shows, previous to March 2020, most of the teachers did not even have the knowledge that the instruments they started to use existed. Only after telework was imposed in the educational system, pre-university teachers learned about online meetings tools such as Zoom, Google Meet or Microsoft Teams. Additionally, Table 4 shows which specific IT\&C skills the interviewed pre university teachers developed during telework.

TABLE 4. IT\&C DEVELOPED SKILLS BY PREUNIVERSITY TEACHERS ( $\mathrm{N}=15)$

\begin{tabular}{|c|c|}
\hline IT\&C DEVELOPED SKILL BY PRE UNIVERSITY TEACHERS & PERCENTAGE \\
\hline CREATING AND MANAGING AN ONLINE MEETING & $98 \%$ \\
\hline WRITING / SENDING E-MAILS & $100 \%$ \\
\hline CREATING DIGITAL MATERIALS (POWER POINT PRESENTATIONS, COMPLEX WORD DOCUMENTS) & $78 \%$ \\
\hline USING GOOGLE INSTRUMENTS & $92 \%$ \\
\hline
\end{tabular}

SOURCE: AUTHORS' CONTRIBUTION

As interviewed teachers mentioned, the effort to adapt to telework was mostly an individual one, as the Ministry of National Education did not offer them any formal technical guidance through this process in the spring of 2020 .

Only after the school year of 2019/2020 finished, the Ministry of National Education started to authorize courses, where teachers could learn more about digital tools. One of the most mentioned courses by the interviewed teachers was "Teacher in Online", an intensive programme started in the summer of 2020 by the association named Digital Nation. This was a course designed to introduce teachers to Google instruments. It was a highly praised programme, but with a big disadvantage, it was not free. The city hall of Bucharest helped young teachers based professionally in the capital city, in the autumn of 2020 by subsiding it entirely, however, this makes us question whether this facility did not create a gap between different age groups of teachers regarding their IT\&C literacy level.

Inventory of the damages and benefits that telework occurred to the educational process September 2021

September 2021 marks the beginning of 2021/2022 school year, the second school year in a row when teachers, students, and parents prepare to face different scenarios of attending classes. Tables 5 and 6 will show the teachers' perception after a year of telework and constant changes, about the benefits and challenges of telework.

TABLE 5. CHALLENGES OF TELEWORK FELT BY PRE-UNIVERSITY TEACHERS ( $\mathrm{N}=15$ ) 


\begin{tabular}{|c|c|}
\hline TYPE OF CHALLENGE & PERCENTAGE \\
\hline KEEPING THE STUDENTS' INTEREST AND MOTIVATION ALIVE & $39 \%$ \\
\hline TRYING TO DELIVER CLEAR \& UNDERSTANDABLE INFORMATION & $22 \%$ \\
\hline CONNECTING EMOTIONALLY WITH THE STUDENTS & $17 \%$ \\
\hline ADAPTING TO PERMANENT CHANGES IN PROCEDURES & $12 \%$ \\
\hline THE EVALUATION SYSTEM & $6 \%$ \\
\hline FEELING SOCIALLY ISOLATED & $4 \%$ \\
\hline
\end{tabular}

SOURCE: AUTHORS' CONTRIBUTION

TABLE 6. BENEFITS OF TELEWORK OBSERVED BY PRE-UNIVERSITY TEACHERS ( $\mathrm{N}=15$ )

\begin{tabular}{|c|c|}
\hline TYPE OF BENEFIT & PERCENTAGE \\
\hline LEAVING AT A SLOWED-DOWN PACE & $37 \%$ \\
\hline INTEGRATING MORE ONLINE RESOURCES & $30 \%$ \\
\hline PUTTING INTO PRACTICE THE IT\&C SKILLS PREVIUOSLY LEARNT & $19 \%$ \\
\hline NO COMMUTE TIME WASTED & $10 \%$ \\
\hline REDUCING PAPER WASTE & $4 \%$ \\
\hline
\end{tabular}

SOURCE: AUTHORS' CONTRIBUTION

As we can observe in Table 5, the challenges of telework perceived by the teachers after a year of using it are slightly different from the ones stated in September 2020 and they no longer target technology, but the people's interaction. The most challenging aspect seems to be how the relationship between students and teachers was developed while classes were held online or in a hybrid system. Teachers' answers show that they felt like their students were losing the interest in school, that they did not have the right instruments to increase students' motivation, and moreover, teachers couldn't receive proper feedback whether the information they were delivering in the online sessions was understandable.

Another interesting aspect about the benefits and challenges of telework in the teachers' case is related to the fact that up to $4 \%$ of them felt socially isolated while teaching online, stating they experienced loneliness, sadness, and lack of inspiration about how to design their work. Nevertheless, most of the benefits teachers indicated for telework target the slowed-down life they lived, as they were no longer exposed to the hustle and bustle from schools and the free time they gained for themselves by the lack of commute.

Additionally, table 6 indicates that among the benefits of telework that teachers perceived, were the possibility to integrate better online resources in their teaching activities, as well as the satisfaction to use skills recently learned (i.e. the skills to use platforms and other IT\&C skills) and to reduce the amount of paper they were using.

Figure 2 shows the most used online platforms in the online teaching, as indicated by the interviewed teachers. When asked about the reasons why one of the platforms was preferred instead of another one, 
Mișu, S-I, Triculescu, M.

LIVING AND TEACHING DURING COVID-19: THE DAMAGES AND BENEFITS OF TELEWORK

most of the teachers explained that it was not their personal choice, but usually it was the school's decision to indicate the agreed one. Based on the received answers, we have made a top of the advantages provided by the Google instruments, as indicated in figure 3 .

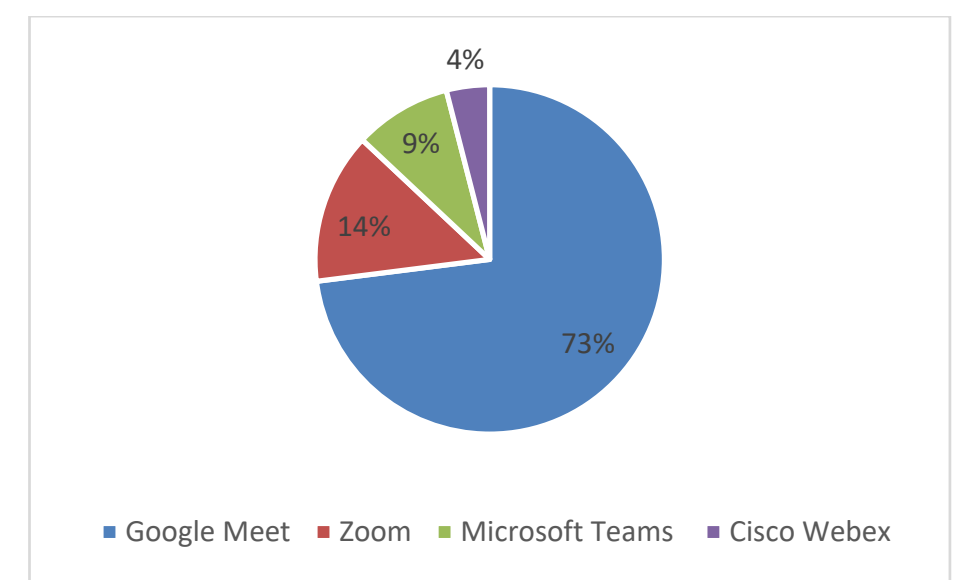

FIGURE 2. THE MOST USED ONLINE PLATFORMS IN ONLINE TEACHING

Source: Authors' contribution

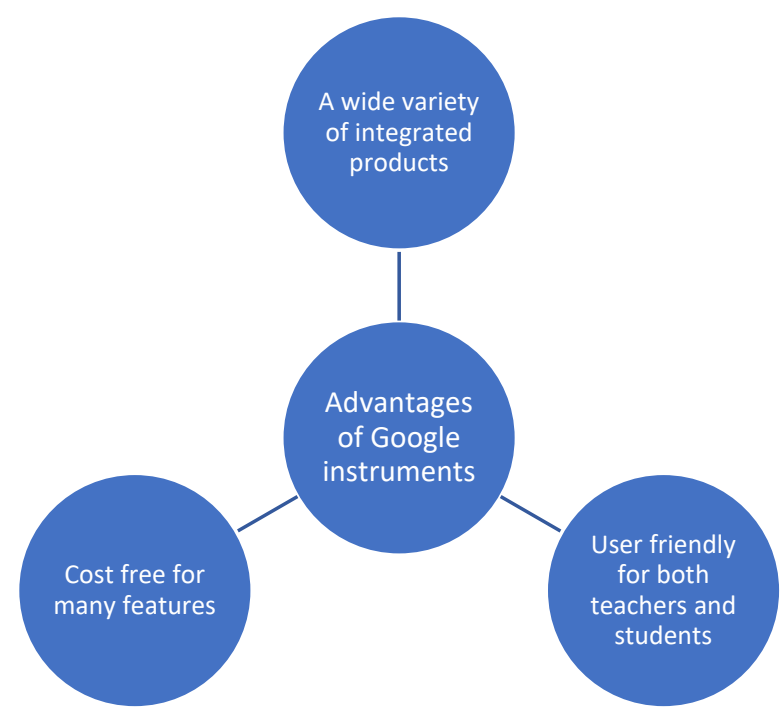

FIGURE 3. ADVANTAGES OF GOOGLE INSTRUMENTS

Source: Authors' contribution

\section{CONCLUSIONS}

This paper's purpose was to present the damages and benefits of telework while living and teaching during COVID-19 by showing the teachers' perception before and after the school year of 2020/2021. This scope 
was approached through the help of an online survey and the help of an interview, tools used at one year distance to evidence the evolution of the teachers' perception.

Findings show us that through the school year of 2020/2021 teachers found particularly challenging how their relationship with the students was developed. On the other hand, during the spring of 2020, teachers mainly struggled with understanding how the platforms worked, how to design an online class and later on, they discovered that keeping students motivated and passing on understandable knowledge was even harder.

Moreover, in terms of the benefits teachers felt while teleworking, most of them said that gaining more time for themselves, slowing down the pace of life, and having the possibility to access resources they couldn't previously, were the most important perks.

The above mentioned findings of our study determine us to conclude that teachers have a good capacity to adapt to new forms of teaching if properly trained and guided, so we suggest to decision makers to invest more resources into this process (e.g. more financial resources will provide equal access to all categories of teachers to trainings; more time for transparent communication will facilitate emotional support and guidance through challenging situations).

Additionally, finding out that one of the most indicated benefits of telework was more free time determines us to believe that further investigations are required for digging into the Romanian teachers work-life balance and for which reasons they needed this extra time for themselves.

Last but not least, we need to acknowledge the strong limitations this study presents. First of all, the sample of examined subjects is a rather small one and it might not indicate representative answers for all category of teachers. There are strong possibilities that a replication of this study in a different geographical context, or in a different age or gender group, to show different results. Additionally, as the context of COVID-19 pandemic is a rapidly changing one, new challenges occur daily in the life of educational stakeholders, hence their perspectives over telework, could as well change.

Finally, we keep the faith that the above presented information can be valuable for all categories of stakeholders that want to keep investigating how telework impacts teachers, as it is a field at its dawn and every day brings to light new perspectives.

\section{REFERENCES}

Alqurshi, A. (2020). Investigating the impact of COVID-19 lockdown on pharmaceutical education in Saudi Arabia - a call for a remote teaching contingency strategy. Saudi Pharm. J. 28, 1075-1083, http://dx.doi.org/10.1016/j.jsps.2020.07.008. 
Debacq, M., Almeida, G., Lachin, K., Lameloise, M.L., Lee, J., Pagliaro, S., Romdhana,H., Roux, S. (2021). Delivering remote food engineering labs in COVID-19 time. Educ. Chem. Eng. 34, 9-20, http://dx.doi.org/10.1016/j.ece.2020.10.002

Ghasem, N., Ghannam, M. (2021). Challenges, benefits \&d drawbacks of chemical engineering on-line teaching during COVID-19 pandemic. Education for Chemical Engineering, 36, 107-114, https://doi.org/10.1016/j.ece.2021.04.002

Li, J., Qin, C., Zhu, Y. (2021). Online teaching in universities during the Covid-19 epidemic: a study of the situation, effectiveness and countermeasures. Procedia Computer Science, 187, 566-573, https://doi.org/10.1016/j.procs.2021.04.100

Misu, S-I. (2020). Teacher's Work Engagement - Change and Adaptation during Covid-19 Pandemic. Business Excellence and Management, Vol. 10, Special Issues 1, October 2020 DOl:https://doi.org/10.24818/beman/2020.S.I.1-19

Radu, I-M., (2021). First Struggles of the Emerging Distance Learning Necessity in Romanian Educational System in the Context of Covid-19. Business Excellence and Management, Vol. 11, Special Issues 2, October 2021 DOI: https://doi.org/10.24818/beman/2021.S.I.2-01 